\title{
Assessment of heavy metal pollution in the sediments of Dwars River, South Africa
}

\author{
Abe Addo-Bediako ( $\square$ Abe.Addo-Bediako@ul.ac.za ) \\ University of Limpopo https://orcid.org/0000-0002-5055-8315 \\ Tebatso Mmako \\ University of Limpopo \\ Millicent Kekana \\ University of Limpopo \\ Wilmien Luus-Powell \\ University of Limpopo
}

\section{Research Article}

Keywords: Trace metals, pollution assessment, sediment, spatiotemporal distribution

Posted Date: September 10th, 2021

DOI: https://doi.org/10.21203/rs.3.rs-891267/v1

License: (c) (i) This work is licensed under a Creative Commons Attribution 4.0 International License. Read Full License 


\section{Abstract}

The Dwars River in Limpopo Province, South Africa is being affected by anthropogenic activities such as mining, agriculture and human settlement in its catchment. The objectives of the study were to assess trace metal pollution, to determine possible sources of pollutants in the river and the potential impact on the ecosystem, aquatic biota and humans. Water and sediment samples were collected and analyzed for the following selected metals: $\mathrm{Cr}, \mathrm{Cu}, \mathrm{Fe}, \mathrm{Mn}, \mathrm{Ni}, \mathrm{Pb}$ and $\mathrm{Zn}$. The enrichment factor (EF) and geoaccumulation index $\left(\mathrm{I}_{\mathrm{geo}}\right)$ were used to determine the extent of trace metal pollution in the sediments. The concentrations of $\mathrm{Cr}, \mathrm{Fe}, \mathrm{Mn}, \mathrm{Ni}$, and $\mathrm{Zn}$ in the Dwars River sediments were much higher than the average shale values, which indicated that the contamination of these metals might be caused by human activities. The enrichment factor (EF) results showed that $\mathrm{Cr}$ and $\mathrm{Ni}$ accumulated to severe enriched level, while the Igeo results indicated that $\mathrm{Cr}, \mathrm{Mn}, \mathrm{Ni}$ and $\mathrm{Zn}$ were strongly contaminated in the sediments. The main sources of pollutants in the area were mining, wastewater/sewage and agricultural discharges. This may pose a serious threat to the aquatic biota and potential human health risk. It is therefore recommended that proper management strategies should be taken to minimize the impact of these metals on the river.

\section{Introduction}

Many freshwater ecosystems are facing a wide range of anthropogenic pressures, such as mining, agricultural and industrial activities (Addo-Bediako et al. 2018; Niba and Sakwe 2018). Trace metal pollution in freshwater ecosystems has become an issue of public health concern due to their toxicity and persistence in the environment. Increased human population coupled with improved standard of living has increased the demand for water, which has resulted in water stress (Edokpayi et al. 2016). The release of mining, agricultural, industrial and domestic effluents without treatment into the environment is a major source of pollution of surface and groundwater water (Afzal et al. 2018; Barut et al. 2018).

Contamination of trace metals in freshwater ecosystems has attracted global attention owing to its abundance, persistence and toxicity in the environment (Edokpayi et al. 2016; Addo-Bediako 2020). When metals are present in higher concentration in an aquatic environment, they can easily be exchanged between the sediment and the water column (Varol and Sen 2012). Sediments are regarded as the secondary source of pollution, thus changes in physicochemical properties such as $\mathrm{pH}$, temperature and ionic strength may cause the bound contaminants to be released into the water column (Hsu et al. 2016). Accumulation of trace metals in sediments is detrimental in an aquatic system and may pose a threat to the aquatic organisms through bioassimilation and bioaccumulation (Dhanakumar et al. 2015; Zhuang et al. 2016; Zhu et al. 2017). When toxic metals bioaccumulate in aquatic biota they are eventually transferred to human beings through the food chain (Islam et al. 2015).

In South Africa, the Olifants River System is one of the major river systems, which provides water for industries, mining, agricultural and domestic uses. The effluents from these activities contain metal pollutants which are contaminating the river system. This has degraded the water and sediment quality 
of many streams and rivers that serve the Olifants River System (Oberholster et al. 2013; Addo-Bediako et al. 2014). In the Steelpoort River sub-catchment of the Olifants River Basin, the sudden increase in mining activities and population has caused the over-exploitation of natural resources releasing of both organic and inorganic compounds into the aquatic streams which may affect aquatic biota and humans.

The Dwars River forms part of the Steelpoort River sub-catchment and serves as a source of water to a number of communities living in the catchment. The river is being polluted by discharge from mining, agricultural and industrial activities in the catchment areas. In the past two decades, mining of chrome and platinum has increased in the area which has resulted in huge influx of migrants, unplanned settlements and industrialization. These may have detrimental effects on the quality of water and sediments of the river and could have a potential long-term effect on the health of the communities in the river catchment, especially those still reliant on untreated water from the river. At present, there have been some reports on trace metal pollution in sediment of the Steelpoort River (Addo-Bediako et al. 2018), but no study has been done on the sediments of the Dwars River. The objectives of the study therefore, were to assess the concentrations of trace metals; chromium ( $\mathrm{Cr}$ ), copper $(\mathrm{Cu})$, iron $(\mathrm{Fe})$, manganese $(\mathrm{Mn})$, nickel $(\mathrm{Ni})$, lead $(\mathrm{Pb})$ and zinc $(\mathrm{Zn})$ pollution and to determine potential sources of pollution in the sediments of the Dwars River.

\section{Methods And Materials}

\section{The study area}

The Dwars River is a tributary of the Steelpoort River, a sub-catchment of the Olifants River in the Limpopo Province, South Africa. The Steelpoort basin lies between 1500 to $2400 \mathrm{~m}$ above mean sea level. The mean annual temperature is about $19.9^{\circ} \mathrm{C}$ and mean annual rainfall is in the range of 630 to $1000 \mathrm{~mm}$ (Mosase et al. 2018). The highest rainfall is usually recorded in summer. Four sites (Fig. 1) were selected to represent the different land use activities; mining, agriculture, human settlements in the river catchment. Site $1\left(24^{\circ} 51^{\prime} 19^{\prime \prime} \mathrm{S} 30^{\circ} 6^{\prime} 9^{\prime \prime} \mathrm{E}\right)$ is in the upstream and it is influenced by mining and cattle grazing. Site $2\left(24^{\circ} 50^{\prime} 34^{\prime \prime} \mathrm{S} 30^{\circ} 5^{\prime} 12^{\prime \prime} \mathrm{E}\right)$ is in the midstream of the river and near mining and smelter plant. Site $3\left(24^{\circ} 49^{\prime} 54^{\prime \prime} \mathrm{S} 30^{\circ} 4^{\prime} 47^{\prime \prime} \mathrm{E}\right)$ is near agricultural fields. Site $4,\left(24^{\circ} 49^{\prime} 50^{\prime \prime} \mathrm{S} 30^{\circ} 4^{\prime} 46^{\prime \prime} \mathrm{E}\right)$ is a few metres from its confluence with the Steelpoort River, there are agricultural activities and informal settlements near the site.

\section{Water and sediment sampling}

Seasonal water samples were collected at the four selected sites during February, April, July September (summer, autumn, winter and spring), 2018. Water samples were collected using $1000 \mathrm{ml}$ acid pre-treated polypropylene bottles. Collected water samples were kept in a container with ice and transported to the laboratory. In the laboratory, the water samples were kept at $4^{\circ} \mathrm{C}$ prior to chemical analysis. During each survey, water temperature $\left({ }^{\circ} \mathrm{C}\right), \mathrm{pH}$, dissolved oxygen (DO) concentration $(\mathrm{mg} / \mathrm{l})$, electric conductivity $(\mathrm{EC}$; 
$\mathrm{mS} / \mathrm{m}$ ), total dissolved solids (TDS; $\mathrm{mg} / \mathrm{l}$ ) and salinity (\%o) were measured in situ at each site using a handheld multi-parameter probe (YSI Model 554).

Surface sediment samples were collected at a depth of 0-10 cm using a spatula. At each site, five subsamples were mixed together, forming a composite sample (Bervoets and Blust 2003). Samples were stored in $500 \mathrm{ml}$ acid pre-washed polyethylene bottles and frozen in the laboratory at $-25^{\circ} \mathrm{C}$ prior to analysis of metals at an accredited laboratory (ISO/IEC 17025: 2005) in Pretoria, South Africa.

The samples were put in acid-washed polypropylene pre-weighed vials and dried at $60^{\circ} \mathrm{C}$ for $24 \mathrm{~h}$. The samples were then sieved through a 2-mm nylon, then $0.1 \mathrm{~g}$ of each sediment sample was digested with $8 \mathrm{~mL}$ of $68 \%$ nitric acid ( $\mathrm{HNO}$ ) and $3 \mathrm{~mL}$ of $40 \%$ hydrochloric acid $(\mathrm{HCl})$. It was then filtered through a membrane filter and the concentrations of the metals were analyzed using inductively coupled plasmaoptical emission spectrometry (ICP-OES) (Perkin Elmer, Optima 2100 DV) (Bervoets and Blust 2003). Concentrations of the metals in the sediments were expressed as $\mathrm{mg} / \mathrm{kg}$ dry weight. Analytical accuracy was determined using certified standards (De Bruyn Spectroscopic Solutions 500 MUL2050STD2) and recoveries were within $10 \%$ of certified values. There are no established national sediment quality guidelines in South Africa, hence the results of trace metals in sediments were compared with the Canadian Interim Sediment Quality Guidelines (ISQG) proposed by the Canadian Sediment Quality Guidelines for the Protection of Aquatic Life (CCME 2012).

Nutrients in the water samples; ammonia $\left(\mathrm{NH}_{4}\right)$, nitrite $\left(\mathrm{NO}_{2}\right)$, nitrate $\left(\mathrm{NO}_{3}\right)$ and phosphate $\left(\mathrm{PO}_{4}\right)$ were analysed at the Biodiversity water laboratory at University of Limpopo using a spectrophotometer (Merck Pharo 100 Spectroquant $^{\mathrm{TM}}$ ) with Merck cell test kits.

\section{Statistical analysis}

The mean and standard deviation of the physicochemical variables, nutrients and metals were calculated. Analysis of variance (ANOVA) was done to determine differences for mean metal concentrations among sites and seasons, using Statistica (Version 10).

The enrichment factor (EF): Enrichment factor is an effective tool to evaluate the extent of contaminants in the environment. The EF for each element is calculated to evaluate anthropogenic influences on trace metals in sediments (Zahra et al., 2014).

Enrichment factor (Barbieri 2016; Hanif et al. 2016). EF is calculated as:

$\mathrm{EF}=\left(\underline{\mathrm{M}_{\underline{\underline{ }}}} \underline{\underline{\mathrm{S}}} \underline{\underline{\underline{x}}}\right)$ sample

$$
\left(\mathrm{M}_{\mathrm{i}} / \mathrm{S}_{\mathrm{x}}\right) \text { reference }
$$

where EF stands for the enrichment factor, (Mi/Sx) sample stands for the ratio of measured value $(\mathrm{m} / \mathrm{kg})$ of element $i$ to measured value $(\mathrm{mg} / \mathrm{kg})$ of reference element $\mathrm{x}$ in the sample, $(\mathrm{Mi} / \mathrm{Sx})$ stands for the ratio 
of background value $(\mathrm{mg} / \mathrm{kg}$ ) of element $\mathrm{i}$ to the background value $(\mathrm{mg} / \mathrm{kg}$ ) of reference element $x$ (Brady et al. 2014; Gao et al. 2014).

The average shale values of metals were used as background values for trace metals (Turekian and Wedepohl 1961). The concentration of Fe was used as a reference value. To account for natural trace metal concentrations, EF is normalized to sediment using Al or Fe content. In this study, Fe was selected while determining EF-values. Iron ( $\mathrm{Fe}$ ) has successfully been used to normalise trace metal contaminants (Bhuiyan et al. 2010).

Geo-accumulation index $\left(\mathrm{I}_{\text {geo }}\right)$

When assessing aquatic toxicity in the sediments, the geoaccumulation index (Igeo) matrix could be applied. The values of the geo-accumulation index is calculated after Muller (1969) by the following equation:

$$
\mathrm{I}_{\mathrm{geo}}=\log _{2}\left(\mathrm{M}_{\mathrm{x}} / 1.5 \mathrm{~B}_{\mathrm{n}}\right)
$$

Where $\mathrm{M}_{\mathrm{x}}$ is the concentration of the examined metal in the sediment, $\mathrm{Bn}$ is the geochemical background value of a given metal in the shale (Turekian and Wedepohl 1961) and the factor 1.5 is used to account for the possible variations in the background values.

Six categories of EF are recognised: and the $I_{\text {geo }}$ index classification consists of seven classes (0-6) (Table 1).

\section{Results And Discussion}

\section{Water quality variables}

The water quality results obtained during the study at different sites are shown in Table

2. The mean water temperature ranged from $17.6^{\circ} \mathrm{C}$ to $21.4^{\circ} \mathrm{C}$. The mean water temperature was highest in summer at Site $3\left(21.4^{\circ} \mathrm{C}\right)$ and lowest in winter at Site $2\left(17.6^{\circ} \mathrm{C}\right)$. In reference to South African inland waters, the permissible water temperature range is between $5-30^{\circ} \mathrm{C}$ (DWAF 1996). Thus, during the study, the water temperature values were within the normal limits. The high temperature at Site 3 , might be due to modified riparian vegetation, as many of the trees have been removed which expose most of the site to direct sunlight. Tree harvesting in riparian zones increases the penetration of light to the water body, thus increasing the water

temperature. The recorded DO concentration was highest at Site 1 , with a mean value of $9.13 \mathrm{mg} / \ell$ and lowest at Site 3 with a mean value of $6.8 \mathrm{mg} / \mathrm{l}$, thus, the DO was within the permissible range limit (DWAF 1996). The highest $\mathrm{pH}$ was recorded at Site 1 and Site 3, while Site 4 had the lowest $\mathrm{pH}$ of 7.4. Seasonally, an increase in $\mathrm{pH}$ was noted during winter, with a value of 8.9 and the lowest during summer, with a value of 7.8. The highest EC value was recorded at Site 3 with a mean of $549 \mathrm{mS} / \mathrm{m}$ and the lowest at Site 4 with a mean of $295 \mathrm{mS} / \mathrm{m}$. Seasonally, summer had 
the highest EC value of $559 \mathrm{mS} / \mathrm{m}$ while autumn had the lowest value of $398 \mathrm{mS} / \mathrm{m}$. The highest salinity mean concentration $(0.46 \%$ ) was recorded at Site 1 and the lowest concentration of $0.21 \%$ o was at Site 4. Seasonally, winter had the highest salinity of $0.63 \%$, while spring had the lowest salinity of $0.23 \%$. The limit for salinity levels in freshwater ecosystems should be $<0.5 \%$ o or not change by $0.05 \%$ from the normal cycle. The TDS recorded was highest at Site 3 and lowest at Site 4.

Most of the trace metals in the water were below detection level (Table 2). Trace metals that were detected were $\mathrm{Cr}$, Fe and $\mathrm{Zn}$, however $\mathrm{Cr}$ was recorded only at Site 1 in summer. The highest concentrations of the $\mathrm{Cr}$, Fe and $\mathrm{Zn}$ metals were recorded in summer and could be attributed to effluent from mining and agricultural activities. The highest mean Fe and $\mathrm{Zn}$ concentrations were 0.43 and 0.08 $\mathrm{mg} / \mathrm{I}$ respectively at Site 1 . The Fe concentration recorded at $\mathrm{S} 1$ and $\mathrm{Zn}$ concentration recorded at all the sites were above the water quality guideline values (DWAF 1996). The relatively high levels of Fe and $\mathrm{Zn}$

at Site 1 in the water column could be due to mining activities in the area, especially ferrochrome mining in the catchment.

All the recorded ammonium concentrations were within permissible limit of $0.2 \mathrm{mg} / \mathrm{l}$ for the aquatic ecosystem (DWAF 1996). The highest nitrite concentration was at Site 1 and the lowest was at Site 4. Generally, nitrites are found at very low levels in an aquatic environment because they are easily reduced to ammonia or oxidised to nitrate by both biochemical and chemical processes (DWAF 1996). The mean nitrate concentration ranged from $1.9 \mathrm{mg} / \ell$ at Site 4 to $16.5 \mathrm{mg} / \ell$ at Site 1 . The concentration at Site 1 was above the permissible limit of $13 \mathrm{mg} / \mathrm{l}$ (BC-EPD 2006). The concentration of ortho-phosphorus at all the sites was above $0.02 \mathrm{mg} / \mathrm{l}$, thus, the water is said to be eutrophic (DWAF 1996). Increase in nutrient levels has the potential to cause eutrophication and may affect the aquatic biota (Griffin 2017).

\section{Trace metals in the sediment}

The mean concentrations of the trace metals, shale and the guideline values are shown in Table 3. The highest mean concentrations of all the metals except $\mathrm{Cr}$ were recorded at Site 4 . The mean concentrations of $\mathrm{Pb}$ and $\mathrm{Zn}$ at all the sites were below the guideline values (CCME, 2012), while that of $\mathrm{Cr}$ exceeded the guideline value at all the sites and $\mathrm{Cu}$ at Site 4.

The mean concentrations of $\mathrm{Cr}$ ranged from 345.7 at Site 4 to $1694.8 \mathrm{mg} / \mathrm{kg}$ at Site 2. The mean concentrations of $\mathrm{Cr}$ far exceeded the background value $(90 \mathrm{mg} / \mathrm{kg})$ at Sites 1 and 2 and the guideline value of $37.3 \mathrm{mg} / \mathrm{kg}$ at all the sites. There was a significant variation in $\mathrm{Cr}$ concentration among the sites $(F=19.32, p<0.0001)$. The high concentration of Cr observed at Site 1 and Site 2, might be attributed to production and processing of ferrochrome (Crafford and Avenant-Oldewage 2011). The concentrations recorded at all the sites and in all the seasons were above the permissible limit and this needs to be seriously monitored as it might impact the aquatic biota. Chromium is associated with allergic dermatitis in humans. It can also damage the liver, lungs and causes organ hemorrhages. Chromium contamination is common in soils and in both ground and surface waters near industrial areas (Katz and Salem, 1994). 
The mean Cu concentrations ranged from 17.1 to $48.0 \mathrm{mg} / \mathrm{kg}$ at Site 1 and Site 4 respectively. The mean $\mathrm{Cu}$ concentration exceeded the average shale value at Site 4 . There was no significant difference in Cu concentration among the sites $(F=2.62, p=0.09)$. Copper is an essential micronutrient required in the growth of both plants and animals. In plants, $\mathrm{Cu}$ is especially important in seed production, disease resistance, and regulation of water. In humans, it is essential in the production of blood haemoglobin, regulation of both the nervous and cardiovascular systems (Rai et al. 2015). However, when $\mathrm{Cu}$ is present in excess, it can alter both the physiological and biochemical processes through generation of free radicals and can cause anaemia, liver and kidney damage, and stomach and intestinal irritation.

The mean Fe concentrations ranged from $56746 \mathrm{mg} / \mathrm{kg}$ at Site 1 to $78094 \mathrm{mg} / \mathrm{kg}$ at Site 4 . The mean Fe concentration in the sediments was higher than the background value $(47200 \mathrm{mg} / \mathrm{kg})$ at all the sites. There was no significant difference in Fe concentration among the sites $(F=1.70, p<0.22)$. The high Fe concentration might be attributed to runoff from chrome mines in the area. Iron is regarded as the most important micronutrient in all living organisms, however, at high concentration it can be toxic (Dallas and Day 2004). Iron has both direct and indirect effects on aquatic ecosystems and it can alter the diversity of aquatic organisms (Edokpayi 2016).

The mean Mn concentrations ranged from $1397.2 \mathrm{mg} / \mathrm{kg}$ at Site 2 to $1767.9 \mathrm{mg} / \mathrm{kg}$ at Site 4 . The mean concentration of $\mathrm{Mn}$ exceeded the shale value of $850 \mathrm{mg} / \mathrm{kg}$ at all sites. There was no significant variation in $\mathrm{Mn}$ concentration among the sites $(F=0.86, p=0.48)$. Manganese is widely used for the manufacture of iron and steel alloys, batteries, glassware, fireworks, fertilizers, fungicides, varnishes, and animal supplementation (Patil et al. 2016). In addition, it is used in some countries as an additive in unleaded gasoline to increase the octane number and reduce the effects of engine knocking (Smith et al. 2018). Manganese in an aquatic environment exists as compound or complexes with other organic compounds (Marsidi et al. 2018). An increased manganese concentration can alter metabolic pathways, specifically, the central nervous system through suppression of dopamine formation (Dallas and Day 2004).

The mean Ni concentrations exceeded the average shale value $(68 \mathrm{mg} / \mathrm{kg})$ at all the sites and ranged from $421.3 \mathrm{mg} / \mathrm{kg}$ at Site 3 to $526.8 \mathrm{mg} / \mathrm{kg}$ at Site 4 . There was no significant difference in concentration among the sites $(F=0.04, p=0.90)$. The major sources of $\mathrm{Ni}$ contamination in the sediments are metal plating industries, combustion of fossil fuels, and Ni mining and electroplating (Khodadoust et al. 2004). In this study, the high concentration recorded could be due to the chrome and platinum mining in the area (Addo-Bediako 2020). High concentration of Ni can cause renal, cardiovascular, reproductive and immunological effects in human (Addo et al. 2012), and can cause cancer and respiratory complications (Oforka et al. 2012).

The mean $\mathrm{Pb}$ concentrations in the sediments ranged from 2.9 to $4.2 \mathrm{mg} / \mathrm{kg}$ at Sites 2 and Site 4 respectively. There was no significant variation in $\mathrm{Pb}$ concentration among the sites $(F=0.49, p<0.69)$. Major sources of $\mathrm{Pb}$ include vehicular emissions, volcanoes, industrial wastes discharge, urban storm 
runoff, atmospheric deposition, erosion and soil leaching (Fatoki et al., 2002), paints and pesticides (ATSTR 2007; Abdullah et al. 2015). Lead can alter haeme from haemoglobin molecule and its toxicity is mostly determined by water hardness, organic materials and pH (Fatoki et al. 2002). During the study, the recorded $\mathrm{pH}$ levels were alkaline which would reduce the toxicity of metals including $\mathrm{Pb}$. Lead is relatively accessible and potentially hazardous and carcinogenic to most forms of life including aquatic organisms (DWAF 1996). It can accumulate in the body and affect the brain, gastrointestinal tract, kidneys, and central nervous system. In children, it can lead to impaired development, lower IQ, shortened attention span, hyperactivity, and mental deterioration (Baldwin and Marshall 1999).

The mean concentrations of $\mathrm{Zn}$ ranged from 30 at Site 1 to $295.3 \mathrm{mg} / \mathrm{kg}$ at Site 4 . There was a significant variation in $\mathrm{Zn}$ concentration among the sites $(F=6.30, p<0.008)$. All the $\mathrm{Zn}$ concentrations recorded were below the average shale value $(95 \mathrm{mg} / \mathrm{kg})$ and CCME guideline value $(123 \mathrm{mg} / \mathrm{kg})$ except at Site 4 . The high zinc concentration at Site 4 could be attributed to the high intensity of mining in the catchment coupled with domestic and industrial runoff. The sources of $\mathrm{Zn}$ in water bodies include mining, coal, and waste combustion and steel processing. Zinc is regarded as an important micronutrient often associated with cadmium in natural environments (Dallas and Day 2004).

The concentrations of $\mathrm{Cr}, \mathrm{Fe}, \mathrm{Mn}, \mathrm{Ni}$, and $\mathrm{Zn}$ in the Dwars River sediments were much higher than the average shale values, which indicated that the contamination of these metals might be caused by human activities. The concentrations of $\mathrm{Cu}$ and $\mathrm{Pb}$ were lower than those of the background values, except $\mathrm{Cu}$ concentration at Site 4, which suggests that these trace metals perhaps came from earth crust. The high concentrations of most of the trace metals in the sediments in the downstream site, Site 4 indicate that metals from upstream are washed downstream and settle in the sediments.

Seasonally, $\mathrm{Cr}$ and $\mathrm{Ni}$ dominated at Site 1 and Site 2 during summer, the percentage of $\mathrm{Cu}$ concentration in summer was highest at Site 3 and in winter at Site 4 . While in summer and spring $\mathrm{Pb}$ had the highest percentage at Site 4. The composition of Fe and Mn were fairly uniform during all the seasons and $\mathrm{Zn}$ distribution was highest at Site 4 during all seasons (Fig. 2). There were no significant seasonal differences in trace metal concentrations for $\mathrm{Cr}, \mathrm{Cu}, \mathrm{Fe}, \mathrm{Mn}, \mathrm{Pb}$ and $\mathrm{Zn}(\mathrm{p}>0.05)$, but there was a significant seasonal variation in the concentration of $\mathrm{Ni}(F=4.36, p=0.02)$. There was no general trend of the distribution of the metals among the seasons (Fig. 3).

\section{Enrichment factor and geo-accumulation index}

The EF) was applied to assess the possible sources of the trace metals. The EF of the trace metals in the sediments of the Dwars River are shown in Table 4. The EF values range from 0.113 to 15.378. The EF values of $\mathrm{Cu}, \mathrm{Mn}, \mathrm{Pb}$ and $\mathrm{Zn}$ were below 2 at all the sites. Thus, the sediments are said to have minor enrichment for these metals. The EF values of Cr were between 2.322 at Site 4 to 15.378 at Site 1, indicating the sediments ranged from minor enrichment to severe enrichment, while Ni shows moderately enriched to moderately severe enriched (see Table 1). The high contamination of $\mathrm{Cr}$ and $\mathrm{Ni}$ is due to 
human activities in the catchment of the river and generally the relatively low concentrations of $\mathrm{Cu}, \mathrm{Pb}$ and $\mathrm{Zn}$ could be due to natural sources (Sojka et al. 2019).

\section{The geo-accumulation index ( $\left.\mathrm{I}_{\text {geo }}\right)$}

When assessing aquatic toxicity, the geoaccumulation index (Igeo) matrix could be applied to assess sedimental contamination. The geo-accumulation index is a quantitative measure of the degree of pollution in sediments (Singh et al. 1997). The quantitative measure of trace metal accumulation (Igeo index) is shown in Fig. 4. Copper, Fe and $\mathrm{Pb}$ remain in grade 0 (unpolluted) at all the sediment sample collected. This suggests that these metals have background values in the sediments of all the sites. However, the Igeo for $\mathrm{Cr}, \mathrm{Mn}, \mathrm{Ni}$ and $\mathrm{Zn}$ reach class 4 (from uncontaminated to strongly contaminated (see Table 1). The high $\mathrm{I}_{\text {geo }}$ values, especially for $\mathrm{Cr}$ and $\mathrm{Ni}$ show that the effluents from various human activities into the river contain high concentrations of these metals (Bing et al. 2019). The diversity of mining activities especially platinum and chrome and metal smelters, and transportation are known to contribute to trace metal pollution in the environment (Baran et al. 2016; Tytła et al. 2019)

\section{Future perspectives}

The main problems in the Steelpoort sub-catchment are salinity, eutrophication, toxicity and sedimentation, as a result of irrigation return flows, mining impacts and sewage treatment plant discharges. It is expected that irrigation in the area would remain relatively modest, while rapid growth in urban populations, mining and energy projects is anticipated to place enormous pressure on the water resources. The establishment of many mining operations in the area in the past two decades has led to an influx of people to the area. It is estimated that more mining operations would be established in the region in the coming years, increasing the demand for water. Climate change will further stress the system as drying is projected across the Olifants River basin. It is therefore a need for cross-sectoral institutional measures and research to alleviate the impact of the constraints.

\section{Conclusion}

The spatial distribution in the sediments of the Dwars River varied greatly. The mean concentrations of $\mathrm{Cr}$, $\mathrm{Fe}, \mathrm{Mn}, \mathrm{Ni}$ and $\mathrm{Zn}$ in the sediments were higher at all the sites than the average shale value and the concentrations of $\mathrm{Cu}$ and $\mathrm{Zn}$ were higher than the average shale value at Site 4 . The concentration of $\mathrm{Cr}$ also exceeded the standard guideline value at all the sites and $\mathrm{Cu}$ and $\mathrm{Zn}$ at Site 4. Enrichment factor ratios showed that $\mathrm{Cr}$ and $\mathrm{Ni}$ were moderately severely enriched to severely enriched in the sediments, while the Igeo showed some form of contamination of $\mathrm{Cr}, \mathrm{Mn}, \mathrm{Ni}$ and $\mathrm{Zn}$ in the sediments. The high concentrations of these metals were mainly influenced by pollution from human activities. Sediments have the potential to release the metals back into the water column, it is therefore important that drastic 
measures are taken to reduce discharges from human activities, such as mining and agriculture into the river. The present study has shown that human activities have a great influence on accumulation of trace metals in the Dwars River. The present data can provide useful information for pollution control strategies and environmental planning in the area.

\section{Declarations}

Funding: The research was supported financially by the Flemish Inter-University Council (VLIR-UOS), Belgium.

Acknowledgements: The author is grateful to the postgraduate students of the Water Laboratory in the Department of biodiversity for their valuable contributions during the field work.

Conflicts of Interest: The author declares no conflicts of interest.

\section{References}

Abdullah M, Fasola M, Muhammad A, Malik SA, Boston N, Bokhari H, Kamran MA, Shafqat MN, Alamdar A, Khan M, Ali N, Eqani SA (2015) Avian feathers as a non-destructive bio-monitoring tool of trace metals signatures: A case study from severely contaminated areas. Chemosphere 119:553-561.

Addo MA, Affum HA, Botwe BO. Gbadago JK, Acquah SA, Senu JK, Adom T, Coleman A, Adu PS, Mumuni II (2012) Assessment of Water Quality and Heavy Metal Levels in Water and Bottom Sediment Samples from Mokwé Lagoon, Accra, Ghana. Res J Environ Earth Sci 4(2):119-130.

Addo-Bediako A (2020). Assessment of Heavy Metal Pollution in the Blyde and Steelpoort Rivers of the Olifants River System, South Africa. Pol J Environ Stud 29(5):3023-3039.

Addo-Bediako A, Marr S, Jooste A, Luus-Powell WJ (2014) Are metals in the muscle tissue of Mozambique tilapia a threat to human health? A case study of two impoundments in the Olifants River, Limpopo, South Africa. Ann Limnol Int J Lim 50:201-210.

Addo-Bediako A, Matlou K, Makushu E (2018) Heavy metal concentrations in water and sediment of the Steelpoort River, Olifants River System, South Africa. Afr J Aquat Sci 43 (4):413-416.

Afzal MS, Ashraf A, Nabeel M (2018) Characterization of industrial effluents and groundwater of Hattar industrial estate, Haripur. Adv Agric Environ Sci 1(2):70-77.

ATSDR (Agency for Toxic Substances and Disease Registry) (2007) Toxicological profile for Lead. Atlanta, GA: U.S. Department of Health and Human Services, Public Health Service.

Baldwin DR, Marshall WJ (1999) Heavy metal poisoning and its laboratory investigation. Ann Clin Biochem 36:267-300. 
Baran A, Tarnawski M, Koniarz T (2016) Spatial distribution of trace elements and ecotoxicity of bottom sediments in Rybnik reservoir, Silesian-Poland. Environ Sci Pollut Res Int 23:17255-17268.

Barbieri M (2016) The importance of enrichment factor (EF) and geoaccumulation index $\left(\mathrm{I}_{\text {geo }}\right)$ to evaluate the soil contamination. J Geol Geophys 5:237.

Barut IF, Ergin M, Meriç E, Avsar N, Nazik A, Suner F (2018) Contribution of natural and anthropogenic effects in the Iznik Lake bottom sediment: Geochemical and microfauna assemblages evidence. Quat Int 486:129-142.

BC-EPD (British Columbia Environmental Protection Division) (2006) Water Quality Guidelines.

Bervoets L, Blust R (2003) Metal concentrations in water, sediment and gudgeon (Gobio gobio) from a pollution gradient: relationship with fish condition factor. Environ Pollut 26:9-19.

Bhuiyan MAH, Parvez L, Islam MA, Dampare SB, Suzuki S (2010) Heavy metal pollution of coal mineaffected agricultural soils in the northern part of Bangladesh. J Hazard Mater 173:384-392.

Bing H, Wu Y, Zhou J, Sun H, Wang X, Zhu H (2019) Spatial variation of heavy metal contamination in the riparian sediments after two-year flow regulation in the Three Gorges Reservoir, China. Sci Total Environ 649:1004-1016.

Brady JP, Ayoko GA, Martens WN, Goonetilleke A (2014) Enrichment, distribution and sources of heavy metals in the sediments of Deception Bay, Queensland, Australia. Mar Pollut Bull 81(1):248-255.

CCME (Canadian Council of Ministers of the Environment) (2012) Canadian water quality guidelines for the protection of aquatic life and sediment quality guidelines for the protection of aquatic life.in.

Canadian Council of Ministers of the Environment, Gatinaeu, QC, Canada.

Crafford D, Avenant-Oldewage A (2011) Bioaccumulation of non-essential trace metals in tissues and organs of Clarias gariepinus (Sharptooth catfish) from the Vaal River System-strontium, aluminium, lead and nickel. Water SA 36:621-626.

Dallas HF, Day JA (2004) The effect of water quality variables on aquatic ecosystem: A review. WRC Report No. TT224/04. South Africa: Pretoria, Water Research Commission.

Dhanakumar S, Solaraj G, Mohanraj R (2015) Heavy metal partitioning in sediments and bioaccumulation in commercial fish species of three major reservoirs of river Cauvery delta region, India. Ecotoxicol Environ Saf 113:145-151.

DWAF (Department of Water Affairs and Forestry) (1996) South African Water Quality Guidelines: Volume 7: Aquatic Ecosystems, Second Edition. Pretoria, South Africa. 
Edokpayi JN, Odiyo JO, Popoola OE, Msagati TA (2016) Assessment of trace metals contamination of surface water and sediment: A case study of Mvudi River, South Africa. Sustainability 8:135.

Fatoki OS, Lujiza N, Ogunfowokan AO (2002) Trace metal pollution in Umtata River. Water SA 28:183-190.

Gao C, Lin Q, Bao K, Zhao H, Zhang Z, Xing W, Lu X, Wang G (2014) Historical variation and recent ecological risk of heavy metals in wetland sediments along Wusuli River, Northeast China. Environ Earth Sci 72:4345-4355.

Griffin, N.J. (2017). The rise and fall of dissolved phosphate in South African rivers. S Afr J Sci 113(11/12). doi.org/10.17159/ sajs.2017/20170020

Hanif N, Eqani SAMAS, Ali SM, Cincinelli A, Ali N, Katsoyiannis IA, Tanveer ZI, Bokhari H (2016) Geoaccumulation and enrichment of trace metals in sediments and their associated risks in the Chenab River, Pakistan. J Geochem Explor165:62-70.

Hsu LC, Hsui L-C, Huang C-Y, Chuang Y-H, Chen H-W, Chan, Y-T, Teah HY, Chen T-Y, Chang C-F, Liu Y-T, Tzou Y-M (2016) Accumulation of heavy metals and trace elements in fluvial sediments received effluents from traditional and semiconductor industries. Sci Rep 6: 34250.

Islam MS, Ahmed MK, Raknuzzaman M, Habibullah-Al-Mamun M, Masunaga S (2015) Metal speciation in sediment and their bioaccumulation in fish species of three urban rivers in Bangladesh. Arch Environ Contam Toxicol 68:92-106.

Katz SA, Salem H (1994) The Biological and Environmental Chemistry of Chromium. VCH, New York.

Khodadoust AP, Reddy KR, Maturi K (2004) Removal of nickel and phenanthrene from kaolin soil using different extractants. Environ Eng Sci 21:691-704.

Marsidi N, Hasan HA, Abdulah SRS (2018) A review of biological aerated filters for iron and manganese ions removal in water treatment. J Water Process Eng 23:1-12

Mosase E, Ahiablame L (2018) Rainfall and temperature in the Limpopo River basin, Southern Africa: Means, variations and trends from 1979 to 2013. Water 10:364.

Muller G (1969) Index of Geo-Accumulation in Sediments of the Rhine River. GeoJournal 2:108-118.

Niba A, Sakwe S (2018) Turnover of benthic macroinvertebrates along the Mthatha River, Eastern Cape, South Africa. Implications for water quality biomonitoring using indicator species. J Freshwater Ecol 33:157-171.

Oberholster PJ, Botha A, Chamier J, De-Klerk AR (2013) Longitudinal trends in water chemistry and phytoplankton assemblage downstream of the rivers WWTP in the upper Olifants River. Ecohydrol Hydrobiol 13:41-51. 
Oforka NC, Osuji LC, Onwuachu UI (2012) Assessment of heavy metal pollution in muscles and internal organs of chickens raised in Rivers State, Nigeria. Int. J Energ. Trends Eng Appl Sci 3:406-411.

Patil DS, Chavan SM, Oubagaranadin JUK (2016) A review of technologies for manganese removal from wastewaters. J Environ Chem Eng 4:468-487.

Rai AN, Ullah A, Haider J (2015) Determination of Acute Toxicity of Copper and Cobalt for Tilapia nilotica. J Bioresour Manag 2 (1). DOI: 10.35691/JBM.5102.0012

Singh M, Ansari AA, Müller G, Singh IB (1997) Heavy metals in freshly deposited sediments of the Gomati River (a tributary of the Ganga River): effects of human activities. Environ Geol 29:246-252.

Smith D, Woodall GM, Jarabek AM, Boyes WK (2018) Manganese testing under a clean air act test rule and the application of resultant data in risk assessments. Neurotoxicology 64:177-184.

Sojka M, Jaskuta J, Siepak M (2019) Heavy Metals in Bottom Sediments of Reservoirs in the Lowland Area of Western Poland: Concentrations, Distribution, Sources and Ecological Risk. Water 11:56.

Turekian KK, Wedepohl KH (1961) Distribution of the elements in some major units of the earth's crust. Geol Soc Am Bull 72:175-192.

Tytła M, Kostecki M (2019) Ecological risk assessment of metals and metalloid in bottom sediments of water reservoir located in the key anthropogenic "hot spot" area (Poland). Environ Earth Sci 78:179.

US-EPA (United States Environmental Protection Agency) (2012) National recommended water quality criteria: Aquatic life. in, United States Environmental Protection Agency.

Varol M, Şen B (2012) Assessment of nutrient and heavy metal contamination in surface water and sediments of the upper Tigris River, Turkey. Catena 92:1-10.

Zahra A, Hashmi MZ, Malik RNG, Ahmed Z (2014) Enrichment and geo-accumulation of heavy metals andrisk assessment of sediments of the Kurang Nallah-Feeding tributary of the Rawal Lake Reservoir, Pakistan. Sci Total Environ 470-471:925-933.

Zhu L, Liu J, Xu S, Xie Z (2017) Deposition behaviour, risk assessment and source identification of heavy metals in reservoir sediments of Northeast China. Ecotoxicol Environ Saf 142:454-463.

Zhuang W, Liu Y, Chen Q, Wang Q, Zhou F (2016) A new index for assessing heavy metal contamination in sediments of the Beijing-Hangzhou Grand Canal (Zaozhuang Segment): A case study. Ecol Indic 69:252-260.

\section{Tables}


Table 1 Classification standard of enrichment factor (EF) and geoaccumulation index(Igeo).

\begin{tabular}{|c|c|c|c|c|}
\hline EF classes & $\begin{array}{c}\text { Enrichment } \\
\text { level }\end{array}$ & Igeo value & Igeo Class & Contamination level \\
\hline $\mathrm{EF}<1$ & No enrichment & Igeo $\leq 0$ & 0 & Uncontaminated \\
\hline $\mathrm{EF}=1-3$ & $\begin{array}{c}\text { Minor } \\
\text { enrichment }\end{array}$ & Igeo $=0-1$ & 1 & $\begin{array}{l}\text { Uncontaminated/moderately } \\
\text { contaminated }\end{array}$ \\
\hline $\mathrm{EF}=3-5$ & $\begin{array}{l}\text { Moderate } \\
\text { enrichment }\end{array}$ & Igeo=1-2 & 2 & Moderately contaminated \\
\hline$\overline{\mathrm{EF}}=5-10$ & $\begin{array}{l}\text { Moderately } \\
\text { severe } \\
\text { enrichment }\end{array}$ & Igeo $=2-3$ & 3 & $\begin{array}{l}\text { Moderately/strongly } \\
\text { contaminated }\end{array}$ \\
\hline$\Xi F=10-25$ & $\begin{array}{c}\text { Severe } \\
\text { enrichment }\end{array}$ & Igeo $=3-4$ & 4 & Strongly contaminated \\
\hline$\exists \mathrm{F}=25-50$ & $\begin{array}{l}\text { Very severe } \\
\text { enrichment }\end{array}$ & Igeo $=4-5$ & 5 & $\begin{array}{c}\text { Strongly /extremely } \\
\text { contaminated }\end{array}$ \\
\hline $\mathrm{EF}>50$ & $\begin{array}{l}\text { Extremely } \\
\text { severe } \\
\text { enrichment }\end{array}$ & Igeo $>5$ & 6 & Extremely contaminated \\
\hline
\end{tabular}

Table 2 Water quality variables and metals recorded at different sites of the Dwars River

\begin{tabular}{|c|c|c|c|c|c|c|c|c|c|}
\hline & S1 & & S2 & & S3 & & S4 & & $\begin{array}{l}\text { Guideline } \\
\text { values }\end{array}$ \\
\hline $\begin{array}{l}\text { Water } \\
\text { variables }\end{array}$ & Mean & SD & Mean & SD & Mean & SD & Mean & SD & \\
\hline Temperature & & & & & & & & & \\
\hline $\begin{array}{l}\left({ }^{0} \mathrm{C}\right) \\
\mathrm{DO}(\mathrm{mg} / \ell)\end{array}$ & $\begin{array}{l}21.3 \\
9.13\end{array}$ & $\begin{array}{l}6.7 \\
1.7\end{array}$ & $\begin{array}{l}17.6 \\
7.5\end{array}$ & $\begin{array}{l}6.1 \\
1.2\end{array}$ & $\begin{array}{l}21.4 \\
6.8\end{array}$ & $\begin{array}{l}6.3 \\
1.4\end{array}$ & $\begin{array}{l}20.8 \\
7.9\end{array}$ & $\begin{array}{l}4.0 \\
1.2\end{array}$ & \\
\hline $\mathrm{DO}(\%)$ & 73.9 & 207 & 66.7 & 201 & 661 & 212 & 758 & 237 & $80-120 \%$ \\
\hline & 8.25 & 0.7 & 8.1 & 0.4 & 8.3 & 0.4 & 7.9 & 0.7 & $6.5-9.0^{3}$ \\
\hline TDS mg/e & 296 & 148 & 308 & 135 & 311 & 135 & 173 & 38.3 & \\
\hline $\mathrm{EC}(\mathrm{mS} / \mathrm{cm})$ & 540 & 102 & 503 & 80.6 & 549 & 71.4 & 295 & 48.0 & $\begin{array}{l}\text { No criteria } \\
\text { available } \\
<0.05 \% \text { or }\end{array}$ \\
\hline $\begin{array}{l}\text { Salinity (ppt) } \\
\mathrm{NO}_{3}(\mathrm{mg} / \mathrm{l})\end{array}$ & $\begin{array}{l}0.56 \\
16.5\end{array}$ & $\begin{array}{l}0.36 \\
4.92\end{array}$ & $\begin{array}{l}0.35 \\
14.8\end{array}$ & $\begin{array}{l}0.15 \\
4.30\end{array}$ & $\begin{array}{l}0.37 \\
14.4\end{array}$ & $\begin{array}{l}0.18 \\
2.43\end{array}$ & $\begin{array}{l}0.21 \\
2.9\end{array}$ & $\begin{array}{l}0.16 \\
2.36\end{array}$ & $\begin{array}{l}<0.5 \% o^{1} \\
13^{2}\end{array}$ \\
\hline $\mathrm{NO}_{2}(\mathrm{mg} / \mathrm{l})$ & 0.33 & 0.1 & 0.03 & 0.01 & 0.03 & 0.01 & 0.02 & 0.0 & $0.06^{2}$ \\
\hline $\mathrm{PO}_{4}{ }^{3-}(\mathrm{mg} / \mathrm{l})$ & 0.04 & 0 & 0.05 & 0 & 0.04 & 0 & 0.04 & 0 & $\begin{array}{l}<0.005 \\
\text { (Oligotrophic) } \\
>0.025\end{array}$ \\
\hline $\mathrm{NH}_{3}(\mathrm{mg} / \mathrm{l})$ & 0.04 & 0 & 0.0 & 0 & 0.04 & 0 & 0.04 & 0 & $\begin{array}{l}\text { (hypertrophic) }^{1} \\
<0.007^{1} \text {; } \\
<0.354^{2}\end{array}$ \\
\hline $\mathrm{Cr}(\mathrm{mg} / \mathrm{l})$ & 0.03 & & $<0.01$ & & $<0.01$ & & $<0.01$ & & $\begin{array}{l}\text { Cr III: } 0.012^{1} \\
; 0.0089^{3}\end{array}$ \\
\hline $\mathrm{Fe}(\mathrm{mg} / \mathrm{l})$ & 0.43 & & 0.19 & & 0.11 & & 0.25 & & $0.3^{3}$ \\
\hline $\mathrm{Zn}(\mathrm{mg} / \mathrm{l})$ & 0.08 & & 0.04 & & 0.05 & & 0.04 & & $0.03^{3} ;<0.12^{4}$ \\
\hline
\end{tabular}


1. (DWAF 1996)-South African Water Quality guidelines: Volume 7: Aquatic Ecosystems.

2. BC-EPD (2006)- British Columbia Environmental Protection Division: Water Quality Guidelines.

3. (CCME 2012)- Canadian Council of Ministers of the Environment: Water Quality Guidelines- Aquatic Life.

4. (USEPA 2012)- United States Environmental Protection Agency: Water Quality Guidelines- Aquatic Life

Table 3 Mean metal concentrations in the sediments of the Dwars River

\begin{tabular}{lllllllllll}
\hline & & Site 1 & & Site 2 & & Site 3 & \multicolumn{3}{l}{ Site 4 } \\
\hline Metals & Shale* & Mean & SD & Mean & SD & Mean & SD & Mean & SD & SQG* \\
\hline $\mathrm{Cr}$ & 90 & 1663.9 & 938 & 1694.8 & 559 & 947.6 & 574 & 345.7 & 568 & $37.3 \mathrm{mg} / \mathrm{g}$ \\
$\mathrm{Cu}$ & 45 & 17.1 & 23.8 & 20.8 & 10.1 & 25.3 & 21.3 & 48.0 & 20.8 & $35.7 \mathrm{mg} / \mathrm{kg}$ \\
$\mathrm{Fe}$ & 47200 & 56746 & 2311 & 59584 & 17994 & 60430 & 7240 & 78094 & 19002 & No guidelines \\
\hline $\mathrm{Mn}$ & 850 & 1427.2 & 173.3 & 1397.2 & 95.11 & 1415.2 & 536.4 & 1767.9 & 338.4 & No guidelines \\
\hline $\mathrm{Ni}$ & 68 & 464.3 & 189.5 & 459.8 & 122 & 421.3 & 248 & 526.8 & 857.3 & No guidelines \\
\hline $\mathrm{Pb}$ & 20 & 2.4 & 1.5 & 3.5 & 1.7 & 2.9 & 1.4 & 4.2 & 1.2 & $35.0 \mathrm{mg} / \mathrm{kg}$ \\
\hline $\mathrm{Zn}$ & 95 & 30 & 34.8 & 40.5 & 48 & 54.3 & 37.3 & 295.3 & 91.3 & $123 \mathrm{mg} / \mathrm{kg}$ \\
\hline
\end{tabular}

*Turekian and Wedepohl (1961); SQG= Sediment Quality Guideline (CCME 2012)

Table 4 Enrichment factor for trace metal in sediments in the Dwars River

\begin{tabular}{crcccccc}
\hline Metal & \multicolumn{1}{c}{$\mathrm{Cr}$} & $\mathrm{Cu}$ & $\mathrm{Fe}$ & $\mathrm{Mn}$ & $\mathrm{Ni}$ & $\mathrm{Pb}$ & $\mathrm{Zn}$ \\
\hline S1 & 15.378 & 0.316 & 1.0 & 1.397 & 5.679 & 0.129 & 0.263 \\
S2 & 14.917 & 0.366 & 1.0 & 1.302 & 5.356 & 0.139 & 0.338 \\
S3 & 8.244 & 0.439 & 1.0 & 1.300 & 4.839 & 0.113 & 0.446 \\
S4 & 2.322 & 0.645 & 1.0 & 1.257 & 4.682 & 0.127 & 1.879 \\
\hline
\end{tabular}

\section{Figures}




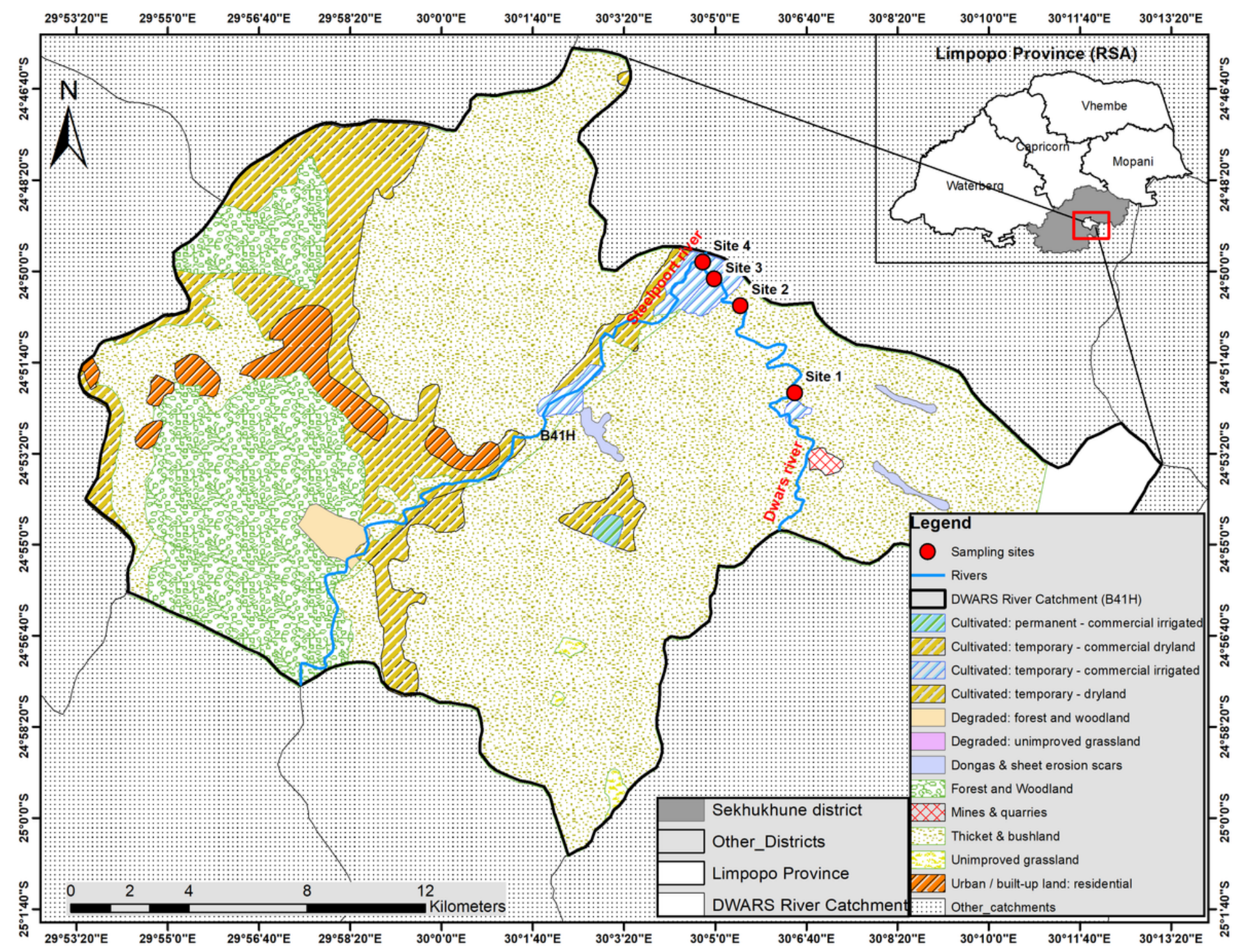

Figure 1

Map of the study area, showing the locations of the sampling sites of the Dwars River. 

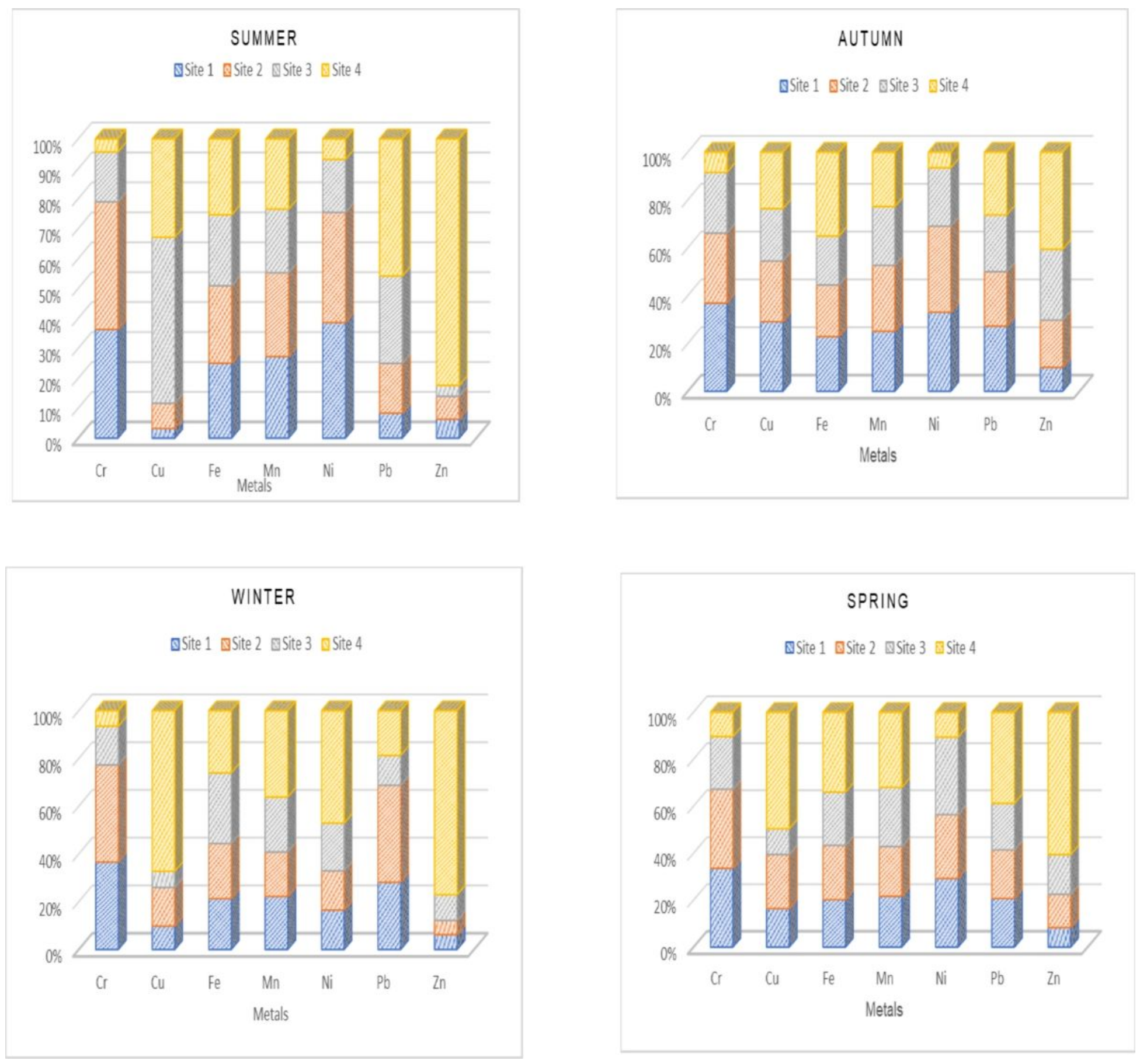

Figure 2

Seasonal distribution of metals in the sediment of the Dwars River at the different sites. 

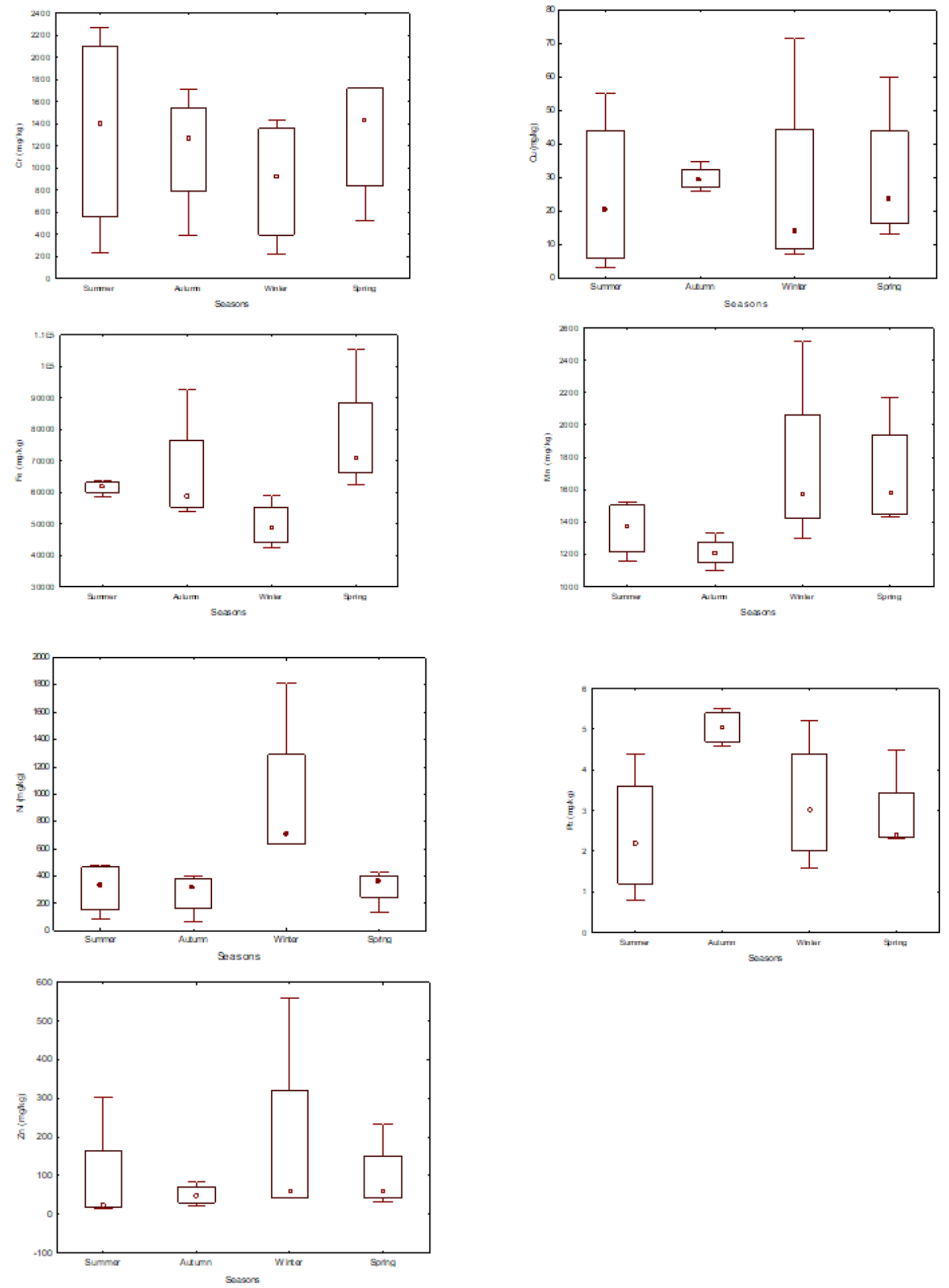

\section{Figure 3}

Box and Whisker plots for the seasonal distribution of trace metal concentrations in the sediments of the Dwars River. 


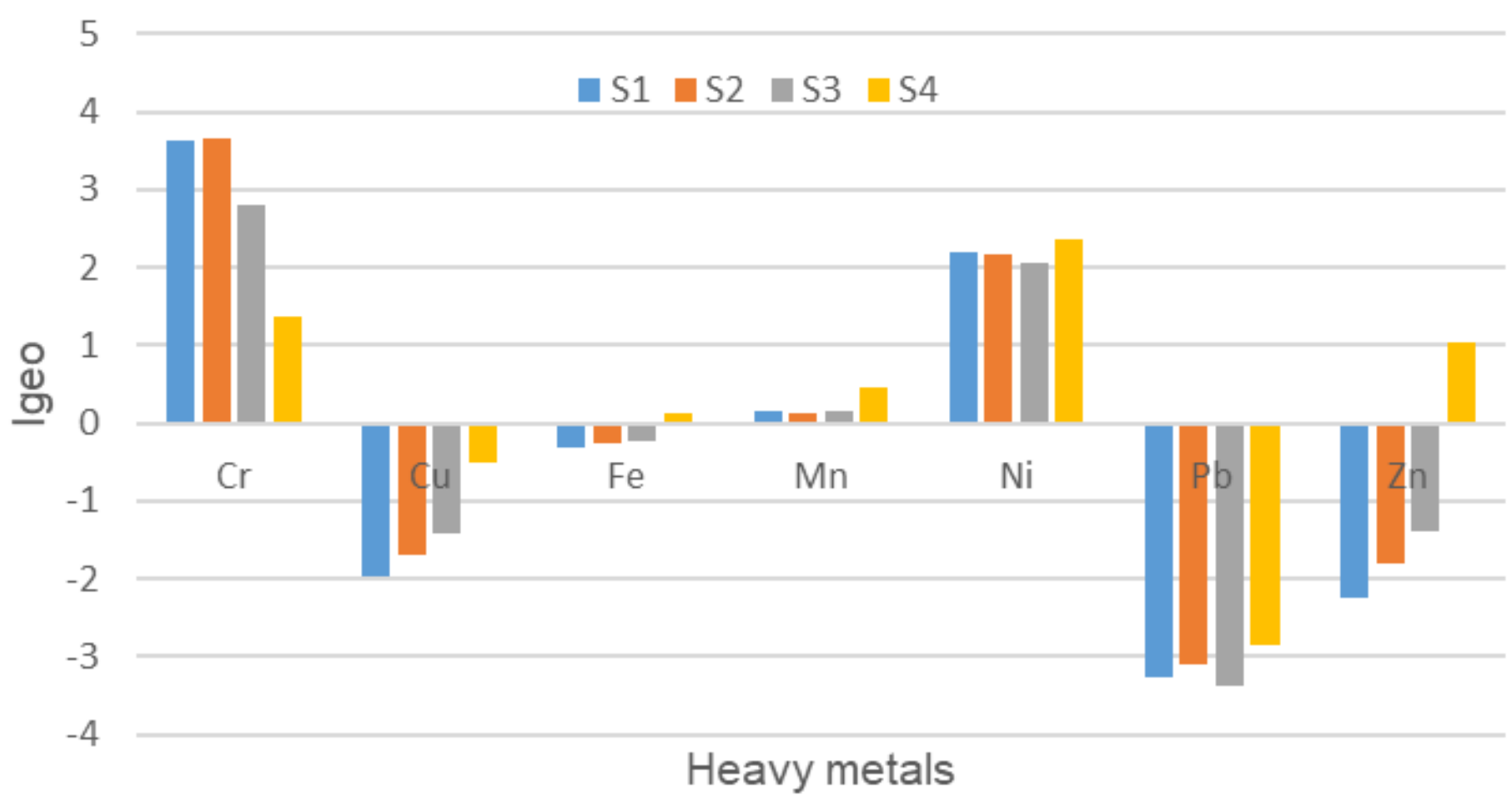

Figure 4

The geo-accumulation index (Igeo) of trace metals in the sediments of the Dwars River.

\section{Supplementary Files}

This is a list of supplementary files associated with this preprint. Click to download.

- AddoBediakoSuppmaterials.docx 